\title{
Debating early modern and modern memory: Cultural forms and effects: a critical retrospective
}

Hiscock, Andrew

\section{Memory Studies}

DOI:

$10.1177 / 1750698017736839$

Published: 23/01/2018

Peer reviewed version

Cyswllt i'r cyhoeddiad / Link to publication

Dyfyniad o'r fersiwn a gyhoeddwyd / Citation for published version (APA):

Hiscock, A. (2018). Debating early modern and modern memory: Cultural forms and effects: a critical retrospective. Memory Studies, 11(1), 69-84. https://doi.org/10.1177/1750698017736839

\footnotetext{
Hawliau Cyffredinol / General rights

Copyright and moral rights for the publications made accessible in the public portal are retained by the authors and/or other copyright owners and it is a condition of accessing publications that users recognise and abide by the legal requirements associated with these rights.

- Users may download and print one copy of any publication from the public portal for the purpose of private study or research.

- You may not further distribute the material or use it for any profit-making activity or commercial gain

- You may freely distribute the URL identifying the publication in the public portal ?
}

Take down policy

If you believe that this document breaches copyright please contact us providing details, and we will remove access to the work immediately and investigate your claim. 


\section{Requested Details}

Name: Andrew Hiscock

Address (postal 2016-18):

Institut de Recherche sur la Renaissance, l'Âge Classique et les Lumières (IRCL)

Université Paul-Valéry, Montpellier III - Site Saint Charles

Route de Mende

34199 Montpellier Cedex 5

France

(email) : a.hiscock@bangor.ac.uk

Affiliation: School of English Literature, Bangor University, Wales/ Université PaulValéry, Montpellier III

Article Title: Debating Early Modern and Modern Memory: Cultural Forms and Effects. A Critical Retrospective

Preferred Running Head: Memory - a Retrospective

Abstract: This discussion focuses upon the ways in which early modern and modern cultural debate examines memory both in terms of its functions and nature as human faculty and of its effects as a cultural phenomenon. It seeks to uncover some of the striking synergies as well as the contrary motions in the vigorous cultural debates surrounding the reflex to remember and its implications for various target audiences. Of particular interest will be the ways in which memory was and is pressed into service to forge critical narratives of origin and belonging at both a personal and collective level, notably with reference to Shakespeare's History plays. Discussion ranges across a number of early modern textual genres (e.g. correspondence; drama; epic poetry; historiography; devotional writing) to probe the prevailing cultural expectations surrounding the exercise of recollection and the consequences of the failure to perform such duties.

Keywords: historiography; humanism; monument; pedagogy; Reformation; Shakespeare.

Article word count: 8210

Brief Biography: Andrew Hiscock is Professor of English Literature at Bangor University, Wales and Marie Skłodowska-Curie Research Fellow at the Institut de Recherche sur la Renaissance, l'Âge Classique et les Lumières (IRCL), Université Paul-Valéry, Montpellier III. He is a Fellow of the English Association, editor (English \& American Lit.) for MLR and series editor of The Yearbook of English Studies. He is series co-editor of the Arden Early Modern Drama Guides. He has published widely on early modern English and French literature and his last monograph is entitled Reading Memory in Early Modern Literature (CUP, 2011). 


\section{Debating Early Modern and Modern Memory: Cultural Forms and Effects. A Critical Retrospective Andrew Hiscock}

Of all faculties in man, Memory is the weakest, first waxeth olde, and decayes sooner then Strength or Beautie [...] now as generally in all things we are forgetfull, so in nothing more then in things belonging to our woes: Either we dare not, or cannot, remember miseries which must befall us. (King, 1992: 69)

In this sermon dating from 1621, Henry King, bishop of Chichester and poet, voiced a complaint familiar to successive generations of early modern readers and audiences, that the failing operations of the faculty for recollection bore ample evidence of the remorseless human decline from a pristine state of spiritual integrity. The implications of such deterioration upon both body and soul were here being deciphered in some detail for the assembled company at St. Paul's Cross in the closing years of James VI/I's reign, but even a cursory encounter with early modern print or manuscript culture soon reveals that the strenuous flexing of the well-tempered memory continued to be promoted as a strategic resource in the Age's ethical and political armoury for government and, indeed, self-government. The Puritan divine Paul Baynes, for example, thundered, 'What makes men sweare, bowze, give place to their lusts, goe on in hardnesse of heart?' - and, not pausing for response, asserted without expectation of demur, 'it is forgetting themselves, and never once considering what they doe, and how they goe on' (Baynes, 1618: 156). At such junctures we may be reminded of Paul Ricoeur's contention in more recent times that 'In remembering something (se souvenant de quelque chose), one remembers oneself (on se souvient de soi)' (Ricoeur, 2004: 96). 
This discussion seeks to uncover some of the striking synergies as well as the contrary motions in the vigorous cultural debates surrounding the faculty of memory in both the early modern and modern periods. It ranges across many different genres, querying the status and function of the faculty in Elizabethan and Jacobean print culture and in Shakespeare's History plays - those extended meditations on the political power of remembering. Indeed, of particular interest in this enquiry will be the ways in which memory was and is pressed into service to forge critical narratives of origin and belonging at both a personal and collective level. As a sequence of recent early modern studies has indicated (e.g. Engel, 1995; Hiscock, 2011; Karremann, 2015; Pivetti, 2015; Lyne, 2016; Engel, Loughnane and Williams, 2016), the narrative drive in successive early modern texts sought to render human experience legible in terms of recovery and retrieval, embedding the faculty to remember in a range of widely available and established intellectual discourses of enquiry - Platonic, Aristotelian, rhetorical, anatomical, architectural, historiographical, chorographical, and scientific.. Indeed, as Raphael Lyne has recently contended, such discourses continually negotiate authority over the faculty: 'The science of memory has great explanatory power in certain contexts and on certain terms, but it does not have a monopoly on that power' (Lyne, 2016: 2). In each of these discursive contexts, early modern readers and audiences were urged, as Baynes demonstrates above, to attend to the very disciplinary nature of memory: not only the ways that changing conceptualisations had penetrated ancient and medieval curricula becoming organising principles for subsequent humanist debates concerning pedagogy, but also the ways in which early modern textual cultures were often powerfully exercised by the possibility that theatre-goers, church-goers, gamesters, itinerants, merchants, and even kin, amongst many others, might succumb to all kinds of amnesia and 'forget' themselves. Indeed, in Of the knowledge and conducte of warres (1578) Thomas Proctor argued that roving agents such as soldiers, 'beinge in daylie daungers of deathe', should 
nevertheless remain mindful that, 'it is seldome or neuer seene the dissolute person to prooue a profitable souldier [...] such bee more meete for an Alehouse then an army. Wherefore good souldier, take thy beginninge of God, Remember first and chyefelie to dyscharge thy duetye towardes him' (Proctor, 1578: 18v). Similarly, the knightly protagonist of Book II of Spenser's The Faerie Queene cautions his errant retainer:

Vnlucky Squire (said Guyon) sith thou hast

Falne into mischiefe through intemperaunce,

Henceforth take heede of that thou now hast past,

And guyde thy waies with warie gouernaunce,

Least worse betide thee by some later chaunce.

But read how art thou nam'd and of what kin. (Spenser, 1590: 242 (II.iv.36))

More generally, throughout this magnum opus, it soon becomes apparent that Spenser's figures, (in Book II, the knightly questers Guyon and Arthur) can only secure an accurate knowledge of who they are and the forward trajectory of their lives by picking over the remains of the past. Within the confines of Alma's (or anima's) castle, Arthur (still lacking a kingdom) and Guyon (beset with tribulations and insufficient knowledge) are presented as studying arduously the dustridden contents of the library in the company of Eumnestes (good memory) and Anamnestes (recollection) (The Faerie Queene, II.ix). In fashioning such tales of chivalric and spiritual labours for Elizabethan consumption, Spenser was renewing the narrative arc of epics inherited from antiquity: in Book I of Virgil's Aeneid, for example, shipwrecked on the shores of Libya, the Trojan prince rallies his men with the passionate appeal: 'The day will come, perhaps, when it will give you pleasure to remember even this.' (Virgil, 1990: 9 (I.203)). However, equally 
importantly, Spenser was also engaging vigorously with paradigms established in the works of nearer contemporaries, Italian epic writers such as Boiardo, Ariosto and Tasso. Profoundly influenced by Ariostan narrative techniques of entrelacement, Spenser's undertaking was equally shaped by the relentless questing for self-completion which characterises the travails of Ruggiero, Bradamante, Isabella and the protagonist himself in Orlando furioso ( $1^{\text {st }}$ pub. 1516). Later, in Tasso's Gerusalemme Liberata ( $1^{\text {st }}$ pub. 1581) the intrepid Rinaldo is discovered declaring to his mistress:

Your deare remembrance will I keepe in minde, In ioes, in woes, in comforts, hopes and feares, Call me your souldiour and your knight, as farre As Christian faith permits, and Asias warre. (Tasso, 1600: 291)

The abiding investments of early modern formulations of memory in narratives of heroism also engage closely with the Ciceronian belief that the retelling of exceptional human experience in historical narrative offered the opportunity for the renewal of past models of virtue in that it 'bears witness to the passing of the ages, sheds light upon reality, gives life to recollection, and guidance to human existence, and brings tidings of ancient days' (Cicero, 1942: 225).

Centuries earlier, Aristotle had famously affirmed in De Memoria et Reminiscentia that the human ability to remember, amongst other acts of cognition, was articulated with a visual lexis'Without an image thinking is impossible' (Aristotle, 1984: 714). Such contentions clearly had a profound influence upon succeeding generations of readers from all spectrums of belief. Indeed, richly sensitive to the manifold temptations on offer to a sinning populace in seventeenth-century London at the beginning of the period of Charles I's 'Personal Rule', the Puritan lawyer and 
vitriolic author William Prynne not only railed in Histrio-mastix The players scourge, or, actors tragaedie (1633) against the activities of the playhouses located in the suspect, seemingly labourless 'liberties' of the city but chose precisely to strike an Aristotelian note by reminding his audience, 'Nothing more powerfully sinkes into the memory, then that which is apprehended by the eye' (Prynne, 1633: 93, 357).

Elsewhere during these early decades of the seventeenth century, Francis Bacon was also considering how play-making might impress itself upon the mind - but from a rather different perspective to that of Prynne. He argued in the sixth book of De Augmentis (1623) that dramatic representation might indeed be beneficial in stimulating the powers of recall: 'stage-playing [...] strengthens the memory, regulates the tone and effect of the voice [...] gives not a little assurance, and accustoms men to bear being looked at' (Bacon, 1857-74: IV.496). Here, Bacon sought to transform the cultural construct of the memory theatre for contemporaneous scrutiny. However, acutely aware of the intellectual deficiencies of his age, Bacon was always able to exercise the minds of his many and various audiences with the very multifariousness of his counsel. In a letter to Sir Henry Savile dating from the final years of Elizabeth's reign, for example, he (like earlier humanist scholars, such as Erasmus in De ratione studii (1511) and Vives in De Tradendis Disciplinis (1531)) recognized that in certain circumstances the faculty of memory might require vigorous training, and advised, 'if want of memory grow through lightness of wit and want to stayed attention, then the mathematics or the law helpeth; because they are things wherein if the mind once roam it cannot recover' (Bacon, 1857-74: VII.102). Thus, in many different contexts, this symbolic practice of remembering returned to the question of governance in the early modern period - to the ethical undertaking of, and ever-present potential for waywardness in, the body politic and its constituent subjects. 


\section{Memory, Self and Soul}

As Frances Yates, Mary Carruthers and Janet Coleman have demonstrated, whether in the ancient, medieval, early modern or modern periods, textual cultures have often compelled their audiences to revisit and re-interrogate the faculty of memory to secure a finer-grained, enhanced understanding of the nature of human subjectivity (Yates, 1966; Carruthers, 1990; Coleman, 1992). Famously in the Confessions, Augustine had promoted memory as a key axis along which to plot the formation of selfhood, declaring, 'It is I who remember, I who am mind [...] Indeed the power of memory is something I do not understand when without it I cannot speak about myself (Augustine, 1991: 193 (X.xvi.25)). In the medieval and early modern periods, this Augustinian emphasis continued to wield a potent influence not only upon intellectual debate, but upon the age's very understandings of epistemology and ontology, as exemplified in William Fulwood's translation of Guglielmo Gratarolo's The castel of memorie (1562), 'take Memorye away: What is a man? What can he doe?/or els what can he say?' (Gratarolo, 1562: A5"). Without the resources of recollection, the existential integrity of the speaking voice disappears and our everyday selves become splintered, fragmented, deprived of their essential unity. Many generations later, in the inter-war years of the twentieth century, R. G. Collingwood argued in his Speculum Mentis, or the Map of Knowledge (1924) that 'A mind which knows its own change is by that very knowledge lifted above change. History, and the same is true of memory [...], is the mind's triumph over time' (Collingwood, 1924: 301). However, by the late twentieth century, cultural theorists such as Richard Terdiman turned to a much less sanguine notion of memory, contending that it cannot be effortlessly integrated into either an Augustinian discourse of renewed spirituality or one of temporal triumphalism: 
Most often we think of memory as a faculty constituting our consciousness and our selfawareness, as the means by which our coherence and our history is constructed and sustained. Such mnemonic activity is fundamental. But there is another side to memory - memory as a problem, as a site and source of cultural disquiet. (Terdiman, 1993: vii)

There remains ample evidence that some early modern minds at least were also acutely aware that memory might constitute 'a site and source of cultural disquiet'. Following in the footsteps of John Leland, early modern antiquarians sought ambitiously to uncover the truths of the evolving narrative of the nation (often identified in topographies and surviving relics and monuments), while simultaneously recognizing the culture of refutation and querying the nation's claims of origination (see Parry, 1995; Vine, 2010). In Britannia ( $1^{\text {st }}$ pub. $1586 ; 1^{\text {st }}$ pub. trans. in English by Philemon Holland, 1610) William Camden acknowledged that, in revisiting and relating the histories of such men as 'Geffray of Monmouth', he used sources 'held suspected amongst the iudicious'. The incremental aggregation of data into a grand narrative of the nation could not allay growing fears for Camden that the textual resources which had survived might be flawed, so a range of different pasts might be competing for position in successive constructions of 'Britannia'. Thus, a chastened chorographer addresses the reader, 'Who shooting all day long doth alwaies hit the marke? Many matters in these studies are raked under deceitfull ashes. There may be some escapes from memorie, for who doth so comprehend particularities, in the treasury of memory, that he can utter them at his pleasure?' (Camden, 1610: *7).

By the Jacobean period, as Dean of St. Paul's, John Donne (never a writer to overlook a potential source of disquiet, spiritual or otherwise) argued at length in his sermons that if the faculty of memory might operate as an initial stimulus to self-knowledge and piety, yet, on other 
occasions, it might also impoverish spiritually and betray the unwary Christian. In his preaching, Donne often revealed himself keenly aware of the dual imperatives of Wisdom 11.12 ('For a double grief came upon them, and a groaning for the remembrance of things past') and of the plaintive submission familiar from the Seven Penitential Psalms: 'Remember, not O Lord our or our parents' offences: neither take vengeance of our sins'. Thus, Donne reminded his congregation, 'in this survey of sin, thy first care must be, to take heed of returning too diligently to a remembrance of those delightful sins which are past; for that will endanger anew' (Donne, 1953-62: I.3.194). ${ }^{1}$

All the proliferating perspectives on memory in these years were enriched by the production and translation of Michel de Montaigne's Essais. Fully conversant with memorial debates inherited from antiquity, the French essayist provocatively submitted that it is commonly seene by experience, that excellent memories do rather accompanie weake judgements' (Montaigne, 1613: 15 (I.ix)). Thus, despite the evidence of this voluminous collection of meditations regaling the reader with his own memorial prowess, Montaigne artfully drew attention to the perceivedly symbiotic, but desperately conflicted relationship that might exist between acts of recollection and cognition: "For memorie representeth vnto vs, not what we chuse, but what pleaseth her' (Montaigne, 1613: 276 (II.xii)). Montaigne well understood that one of the most significant ways in which the intellect was invited to invest in memoria in early modern culture was through the renewed commitment to historia. Indeed, across the Channel in post-Reformation England, the widespread commitment to the reading, writing, translation of and commentary on scripture and Greco-Latin texts constituted a significant, recurring response to an acutely felt cultural void - a response to a profound, but lately silenced, desire to venerate. This desire had hitherto been reserved for seemingly ageless relics, sacred spaces and the precious rituals of Catholic Christendom. However, how might the well-practised power of recollection 
continue to be admired, when that which was in living memory was tainted by the 'old faith'? The enormous claims of Catholic Christendom upon all areas of intellectual life in the medieval West had meant that remembering became a conspicuous feature of all kinds of acts of piety: preaching; collective prayer; pilgrimage; personal devotion; the commemoration of the dead; the veneration of saints; the sacrament of confession; monastic practices and writings which focused precisely upon the enhancement of spiritual interiority. ${ }^{2}$ Subsequent early modern centuries remained richly sensitive to these emphases. Indeed, in one of his customary attacks upon Stoical thinking, Erasmus paid particular attention to the travails of mind and body, enquiring in his De Contemptu Mundi (1521),

Has anyone ever weighed up the terror of a seething heart, the violent uprising that rends the heart, the factions that pull it this way and that, shaking it up, plucking and tearing it apart? Memory serves as its prosecutor, the mind sits as its judge, and conscience plays the executor. Reason beckons this way, nature another, the desire to sin a third. Hence a continual goading on, a continual struggling and battling. (Erasmus, 1988: 163).

Unsurprisingly, given the longevity of such practices of Catholic devotion, successive generations of Reformists remained alert to the accusation that they were committing themselves to a newfound form of worship with no deeper roots that those of an inauthentic present. In sixteenthcentury Europe, faith communities remained sensitive to this damning charge of novelty which might be made by adversaries against any assertion of authority. Calvin himself reputedly enquired, 'Who will venture to place the authority of Copernicus above that of the Holy Spirit?' (Stimson, 1917: 46-47); and, across the religious divide of Europe in Catholic Spain, Claudio Aquaviva urged his fellow Jesuits, 'Let us try, even when there is nothing to fear for faith and 
piety, to avoid having anyone suspect us of wanting to create something new or teaching a new doctrine [...] Let no one adopt new opinions in the questions already treated by other authors' (Ariew, 2012: 40). This certainly contextualises Hythloday's sardonic observation in More's Utopia that scholars would consider it

'[...] a very dangerous matter if a man were found to be wiser in any point than his forefathers were. As a matter of fact, we quietly neglect the best examples they have left us; but if something better is proposed, we seize the excuse of reverence for times past and cling to it desperately. Such proud, obstinate, ridiculous judgments I have encountered many times, and once even in England.'

'What!' I asked. 'Were you ever in England?' (More, 1992: I.8-9)

A century after Utopia, figures like Bacon might be found affirming the crucial significance of innovation, introduction, experimentation in what he termed the 'proficience' of the human condition. He argued in treatise after treatise that the (early) modern age was not condemned to revive and repeat the flawed actions and knowledges of the past: as the human intellect embraced new interpretative possibilities of its material existence, in turn new, more fruitful trajectories from the past might be envisaged. Others, however, were more interested in renewal and renovation than innovation. Nearly a century earlier, Erasmus asserted that 'to restore great things is sometimes not only a harder but a nobler task than to have introduced them' (Erasmus, 1976: 221-2).

During Elizabeth's reign, in his own painstaking engagement with the labours of earlier historians, John Foxe was determined to throw back upon Catholics the familiar complaint levelled at Reformers that they had no history, no memory, no past in which to anchor their 
cultures of worship. In retaliation, Foxe demanded imperiously at the opening of the Acts and Monuments, 'I aske here of this Romaine clergie, where was this church of theirs which nowe is, in the old auncient time of $\mathrm{b}^{\mathrm{e}}$ primitiue church of Rome, with this pompe $\&$ pride, $\mathrm{w}^{\mathrm{t}}$ this riches \& superfluitie, with this gloria mundi [?]' (Foxe, 1570: 28). Understandably, in an age which customarily drew sustenance for all its organising principles of authority, legitimacy and difference, indeed the very notion of human dignitas itself, from its relations with the past, the cultural drive of each faith community was to commemorate and to resist the onset of change in its self-conceptualisation.

\section{Shakespeare and the Production of Memory}

Michel de Certeau contended that 'History is probably our myth. It combines what can be thought, the "thinkable", and the origin, in conformity with the way in which a society can understand its own working' (Certeau, 1988: 21). This indomitable fascination with forging, strengthening, consolidating relations with the past as part of a larger process of social enquiry clearly manifested itself not only in the burgeoning production of chronicles, martyrologies, chronographies, classical translations and biographies in the early modern period, it was also witnessed in the development of a national history for theatrical consumption. A vigorous investment in retrieving (and producing) memorial narratives is one shared by characters and audiences alike (on- and off-stage) in Shakespeare's (and his collaborators') History plays where competing narrative recessions are accompanied by a keen and growing realisation of the penetrating experiences of lack, loss and absence in the present.

The production of these Histories in the 1590s represented a key contribution to the unending debates in late Elizabethan England concerning, amongst other questions, the ambitions and implications of militarised society. Indeed, as they endure the urgent dual threats 
of moral and political collapse in their societies, the inhabitants of these plays (and their audiences) are called upon to probe the bitterly competitive nature of remembering - the ways in which we choose to re-encounter and valorise the conflicts of the past for political gain. Kyle Pivetti has recently returned attention to the strategic (and potentially therapeutic) deployment of memory arts in the period wherein 'violence [...] ensures retention. [...] By imagining an act of destruction upon those one values (or despises), he or she can protect his or her own memory from failure. The memory image takes advantage of the speaker's fear, using his or her reactions to vivid violence in service of a mnemonic strategy. The most effective memory image will be that which imagines calamity, repeating destruction in service of another rhetorical goal' (Pivetti, 2015: 45). The specifically monitory value of spectacular violence and misfortune is communicated in the remorseless theatre of bloodletting which characterises the early Histories. Strategically, the scaffolding of the Henry VI plays is both reliant upon and dismantled by 'That ever living man of memory,/Henry the Fifth' (Shakespeare, 1990: 151 (1 Henry VI - IV.iii.512)). ${ }^{3}$ However, in the aftermath of great King Harry's passing, the English nation is wracked by the trauma of bitter division and collapsing narratives of collective belonging and achievement.

In Time and Narrative Paul Ricoeur argued that 'time becomes human time to the extent that it is organised after the manner of a narrative' (Ricoeur, 1984: 3), and in the Henry VI plays the endlessly renewing narratio of an absent patriarch spawns a seemingly endless succession of morally unremarkable countercultures, characterised principally by their faithlessness and stunted vocabulary of brutality. Nonetheless, recollections of Henry V's sovereignty are soon forced to struggle for their place against earlier, medieval precedents for the exercise of power: at Rouen, Talbot's thoughts are monopolised by the memory that 'in this late-betrayed town/Great Coeur-de-lion's heart was buried' (Shakespeare, 1990: 131 (1 Henry VI - III.ii.82-3)), whereas in 3 Henry VI, Oxford is prompted to remind his auditors of 'great John of Gaunt,/Which did 
subdue the greatest part of Spain' (Shakespeare, 1999: 144 (III.iii.81-2)). Clearly, the late Elizabethan playhouses remained alive to the empowering synergies, the creative possibilities, which were excited when memoria was placed in close proximity to narratio. As often appreciated, early modern educationalists pondered the value of the ars memoriae inherited from writers such as Quintilian, Cicero and from the Rhetorica ad Herennium: in such discussions, the public speaker might retrieve significant information as his powers of concentration travelled imaginatively through mental images of complex edifices or arresting scenes, visiting each remembered locus in turn. In the Institutio Oratoria, for example, Quintilian advises that 'Some place is chosen [...] such as a spacious house divided into a number of rooms [...] The first thought is placed, as it were, in the forecourt; the second, let us say, in the living room; the remainder are placed in due order $[. .$.$] as soon as the memory of the facts requires to be revived, all these places$ are visited in turn and the various deposits are demanded from their custodians' (Quintilian, 1936: 213, 221, 223 (IV.xi.2.1, IV.xi.18, IV.xi.20-1)). Raphael Lyne has highlighted recently that the 'medieval memory arts aimed to assuage the effects of human frailty, whereas Renaissance exponents sought to harness the power of the human mind, and to equip it to apprehend the whole world' (Lyne, 2016: 4). In contrast, Shakespeare's history plays transport us to a benighted netherworld, remote and unmoved by the Renaissance veneration for the 'piece of work' that is 'man'.

In this context, Ricoeur has queried whether 'historiography in a certain way [is not] the heir of the ars memoriae, that artificial memory [...] a way of expressing memorization turned into an exploit?' (Ricoeur, 2004: 141-2). The History plays probe precisely this relationship between recollection, exploit and collective belonging. 1 Henry VI, for example, opens at an irrevocable moment of cultural parturition in the wake of Henry V's death: Bedford proclaims, 'Hung be the heavens with black! Yield day to night!' (Shakespeare, 1990: 66 (I.i.1)). By the opening of 2 
Henry VI, the union of the failed state with Margaret of Anjou is not signalled as a moment for national celebration at the English court. Indeed, the regent Gloucester holds the alliance to be a prelude to chaos, occasioned by the ills of collective amnesia: 'O peers of England, shameful is this league,/Fatal this marriage, cancelling your fame,/Blotting your names from books of memory,/[...] Undoing all, as all had never been!' (Shakespeare, 1991: 84 (I.i.95-7, 100)).

The history plays, indeed, strikingly endorse Freud's contention that 'There is in general no guarantee of the data produced by our memory' (Freud, 1953-74: 3:315), producing narratives which have succumbed to the operations of excision, supplement and unexpected tempi - all practices with which the faculty of memory itself is intimately acquainted. As dramatic characters scavenge amongst narratives of former experience for traces of possible claims to authority and as their lives on the early modern stage are unhistorically stretched, edited or curtailed in these accounts of the vicissitudes of fifteenth-century England, audiences are compelled to examine at close quarters their own appetites for renewed knowledge of origination and legitimation to be derived from the remains of the past.

In his landmark study La Mémoire collective (1950), Maurice Halbwachs stressed for the mid-twentieth century that 'Society from time to time obligates people not just to reproduce in thought previous events of their lives, but also to touch them up, to shorten them, or to complete them so that, however convinced we are that our memories are exact, we give them a prestige that reality did not possess' (Halbwachs, 1992: 51). The dramaturgy of these History plays impresses upon us in a host of different ways that our memories are irrepressibly creative perhaps because they need to be. In a reality where the human mind only ever has insufficient data at its disposal, recovery of the past must rely to a lesser or greater extent upon leaps of the imagination. 


\section{Memory and Political Narrativisation}

Earlier in his discussion, Halbwachs urged his readers to be mindful of the strategic role of memory in the formulation of a collective consciousness: 'in order to remember, one must be capable of reasoning and comparing and of feeling in contact with a human society that can guarantee the integrity of our memory' (Halbwachs, 1992: 41). When we take our leave from the communal undertakings of remembering, like Shakespeare's Hamlet, for example, Halbwachs affirms that we seek out through the exercise of memory another form of community:

In a way, contemplative memory or dreamlike memory helps us to escape society. [...] Yet, if we flee in this way from the society of the people of today, this is in order to find ourselves among other human beings and in another human milieu, since our past in inhabited by the figures of those we used to know. In this sense, one can escape from a society only by opposing to it another society [...] (Halbwachs, 1992: 47)

As we have seen, William Camden constantly reviewed the textual bloodlines for nation-building he had inherited. In direct comparison, a generation earlier, Foxe had repeatedly bewailed the threadbare nature of some of his sources for the Acts and Monuments ('Would to God that the constant diligence of our predicessours had preserued in memory for vs the whole order of their life' (Foxe, 1563: 137).Ralegh in the opening years of James VI/I's reign remained equally tested when seeking to uncover indisputable truths from the circuitous temporum, or cyclical course of time, for his History of the World (1614), despairing of humanity ever being able to draw fruit from the faulty workings of memory: 'so we neither looke behinde vs what hath beene, nor before vs what shall be' ('The Preface', in Ralegh 1634: B2v). Nonetheless, generation after generation, early modern writers and readers sought out the guidance of historical precedent. The desire to 
decipher the present through a knowledge of antiquity, most especially its theatres of war and political strife, continued throughout the early modern period to be catered for by the printing presses. Alexander Barclay's translation of Sallust's famous cronycle of the warre appeared in 1522, for example, and was followed in 1544 by Anthony Cope's historie of two noble capitaines of the worlde, Anniball and Scipio [...] out of Titus Liuius, as well as numerous notable examples of the genre in the second half of the century. At the beginning of the seventeenth century, Sir Clement Edmondes, 'remembrancer of the Citie of London', published Obseruations wpon the fiue first bookes of Caesars commentaries setting fourth the practise of the art military [...] for the better direction of our moderne warres (1601); such translations circulated alongside the Latin editions of writers such as Caesar and Tacitus which were being taken up in classrooms and libraries across Europe. Indeed, in a prefatory letter at the opening of Holinshed's Second volume of Chronicles: Conteining the description, conquest, inhabitation, and troblesome estate of Ireland (1586), John Hooker asserted that his contemporaries might unhesitatingly follow in the steps of their classical forebears for 'Iulius Caesar also in his wars searched the ancient bookes and histories of the citie of Rome' in order to 'draw a paterne for his owne direction, both for his ciuill and his martiall affaires' (1586: $\left.\mathrm{A} 2^{v}\right)$.

Ralegh is a notable example of a scholar who did not restrict the exercise of memory to his incursions into print culture. During the 1580 s when he was funding voyages to establish colonies in Virginia, he was also recruiting settlers to populate lands in the counties of Cork and Waterford in the wake of the devastation brought on by the quashing of the 1583 Desmond Rebellion. In 1587, Ralegh was finally in receipt of a grant of some 42,000 acres of land in the Munster plantation; and in 1589 he sought refuge there, having fallen foul of the Crown's displeasure. This was an experience he would encounter again in the early 1590s when news of his secret marriage to the lady-in-waiting, Elizabeth Throckmorton, became public knowledge, 
and the disobedient couple retreated to on his Dorset estate of Sherborne. From this retreat, this errant knight now had the leisure to examine the travails past and present of the Crown's dealings with its subjects. Regarding the latest 'Irish combination' in 1593, for example, Ralegh wrote imperiously to Robert Cecil on $10^{\text {th }}$ May: 'Her Majesty hath good cause to remember that a million hath been spent in Irland not many yeares since. A better kingdome would have bynn purchased att a less prize and that same defended with as many pence if good order had bynn taken' (Ralegh, 1999: 93-4). Some three years later, in A View of the Present State of Ireland (1596) Spenser would advocate the dissolution of the Irish septs and the enforcement of individual surnames upon the inhabitants. This, it was argued, would lead to a decay in collective loyalties and compel the Irishman [sic] 'in short time [to] learn quite to forget his Irish nation' (Spenser, 1970: 156). If, in the nineteenth century, Emerson insisted that memory was 'a primary and fundamental faculty, without which none other can work; the cement, the bitumen, the matrix in which the other faculties are imbedded' (Emerson, 1899: 63), it appears that an increasing number of voices were clearly being heard in Elizabethan England, advocating the dissolution of this 'cement', this 'bitumen', amongst those it wished to colonise for their nation's (and one may believe, their own) greater political ascendancy and economic prosperity.

\section{The Discipline of Memory}

Early modern debates surrounding memory were customarily shaped by expectation of moral and/or pious action. This commitment had been bequeathed by earlier generations of intellectuals who not only deployed memory as a resource for ethical education, spiritual improvement and public service, but who also sought to evaluate the most sympathetic conditions in which it might thrive (see Hiscock, 2011: 15ff). Juan Luis Vives, a frequent visitor to Henry VIII's England, highlighted, for example, that 'What we want to remember must be 
impressed on our memory while others are silent; but we need not be silent ourselves, for those things which we have read aloud are often more deeply retained. In the same way we remember better what we have heard from others than what we have read ourselves' (Vives, 1913: 109).

In De Inventione Cicero had notably placed memoria as a subdivision of Prudentia and his taxonomy continued to have enormous influence in succeeding centuries not only in the writings of Augustine (who, in the Confessions, argued that memory became the venter animi or 'the stomach of the mind' - 10.14.21), but also in the writings of pre-eminent medieval thinkers such as Albertus Magnus and Thomas Aquinas, who both executed commentaries of Aristotle's De Memoria et Reminiscentia. In De Bono Albertus promoted memory at the heart of the Christian's moral life: 'Prudence is the knowledge of the good and evil of actions; this knowledge, moreover, is greatly aided by events that have already happened, because by means of the past it will know in what way it should manage itself in the future; therefore memory should be part of prudence' (Carruthers, 1990: 268. See also Coleman, 1992: 62ff). Aquinas in his own commentaries upon Aristotle's De Memoria et Reminiscentia emphasised that 'The role of prudence is to direct the prudent man to do what ought to be done by considering not only the present but also the past. This is why Cicero sets down as the parts of prudence not only foresight [...] but also understanding [...] and memory' (Aquinas, 2005: 184). If Peter Burke has argued that 'Remembering the past and writing about it no longer seem the innocent activities they were once taken to be. Neither memories nor histories seem objective any longer' (Burke 1989: 98)', there is ample evidence in the early modern period that to remember all too often constituted an undertaking of religious and/or political engagement. Following precepts set down in the social theorising since antiquity, at the close of the Jacobean period the French (Huguenot?) émigré Caleb Dalechamp envisaged a community of public servants offering up their talents to the polis. He affirmed in his Artis poeticae et versificatoriae encomium (1624) that 'Memory is not only 
conducive to learning but also brings no small assistance to our civil life' (Dalechamp, 1999: 1687). ${ }^{5}$ Clearly, superlative moral (and memorial) exempla might not only be discovered by early modern readers in contemporaneous editions of antique history and Scripture, but also in Foxe's martyrologies, Bacon's meditations on natural philosophy, Ralegh's ruminative writings or the tours de force offered by the memory experts who inhabited the playhouse stage or the pulpit. A popular collection such as A Helpe to memory and discourse with table-talke as musicke to a banquet of wine ( $1^{\text {st }}$ pub. 1619 , attributed to William Basse $)^{6}$ indicates that the performative spaces for memory (and, interestingly, prophecy) were legion and might be encountered at any point in the everyday lives of early modern England:

And now of late yeeres was there a woman, one Mistresse Iostlin of Cambridgeshire, who for excellency of memory deserues here to be remembred, who by vse and moderate preseruation thereof, was so strong and quicke, that vpon the first rehearsall she was able to repeat 40. lines Latine or English, and to carry a whole Sermon from Church, and after set it downe almost verbatim in her chamber. She wrote a Legacy to her child before it was borne, and prophesied of her owne death, and died accordingly at the time. (Basse, 1630: 20-1)

Reviewing such questions in the final years of Elizabeth's reign, Sir William Cornwallis contemplated in his own Essayes (1600-1601) the very multifariousness of opportunities open to all members of the polity to express evil acts and thoughts and how 'their resistance is reasons office'. Indeed, he argued how we must commit ourselves to, what he termed, a 'mustering' of 'the good': 'The often vsing these thoughts, ends with the practise to a thing often read, the memory will lead as well as the eyes, we cannot thinke well often, but we shall do well sometimes, 
and then vertue is gotten by hart, which before was but counsel' (Cornwallis, 1600-1601: Q8'). Here, as Aristotle had counselled, the faculty of memory is seen to operate symbiotically with visual consumption of the world around us to produce strategic acts of cognition. However, for a generation later traversing the divisions created by the civil wars of the 1640 s, Sir Thomas Browne in Hydriotaphia, or Urne-Buriall (1658) seems to have found modest consolation in the knowledge that to be 'ignorant of evils to come, and forgetfull of evils past, is a mercifull provision in nature, whereby we digest the mixture of our few and evil dayes, and our delivered senses not relapsing into cutting remembrances, our sorrows are not kept raw by the edge of repetitions' (Browne, 1658: 78).

\section{Concluding Thoughts: Memory and Monument}

Montaigne pleaded in the course of his Essais that 'Nous ne travaillons qu'à remplir la mémoire, et laissons l'entendement et la conscience vuides [...] Sçavoir par cour n'est pas sçavoir; c'est tenir ce qu'on a donné en garde à sa mémoire' (Montaigne, 1878; 103, 119). ${ }^{7}$ As we witnessed at the opening of this discussion, such angles of vision are often intimately connected to the age's ebbing faith in our powers to remember adequately. Bearing witness in Shakespeare's tragedy Othello to his failing powers of apprehension, Cassio submits, 'I remember a masse of things, but nothing distinctly' (Shakespeare, 2003: 118 (II.iii.264)), and at his first trial in 1603 shortly after the accession of James I to the English throne, Ralegh pleaded before his accusers in the court: 'Only this, I desire: sickness hath of late weakened me, and my memory was always bad; the points in the indictment are many, and in the evidence, perhaps, more will be urged. I beseech you, therefore, my Lords, let me answer the points of the evidence severally, as they are delivered; for I shall not carry them all in my mind to the end' (Jardine, 1832: I.402). 
The endeavours to 'memorialise' others by means of textual monuments are widely in evidence throughout the early modern period. We might look to the Mary Sidney's overseeing of the editing of her brother Philip's literary works after his death, John Foxe's remorseless accounts of the maiming and execution of martyrs, or Thomas Bentley in his 1583 accounts of 'matrones conteining seuen seuerall lamps of virginitie, or distinct treatises'. However, in the first Act of 1 Henry VI Charles, Dauphin of France, indulges in an even more widespread early modern activity of memorialisation which continued to orient the spiritual, civic and labouring lives of many across the nation: the commemorative practices surrounding architectural monumentalisation. ${ }^{8}$ If Joan la Pucelle proves victorious at the head of the French forces at Orleans, Charles pledges:

A statelier pyramis to her I'll rear

Than Rhodope's or Memphis' ever was:

In memory of her when she is dead,

Her ashes, in an urn more precious

Than the rich-jewel'd of Darius,

Transported shall be at high festivals

Before the kings and queens of France. (Shakespeare, 1990: 96 (I.vi.21-27))

In this particular dramatic narrative, of course, Joan is not allowed to defeat the English or Time in any enduring manner, and she enjoys a lion's share of the demonisation reserved for England's antagonists in this play. More generally, however, the widespread human endeavours in the early modern period to signal a textual, political and/or architectural legacy would meet with scorn in the next century under the lens of Sir Thomas Browne. Pondering initially in Hydriotaphia 
Pythagorean formulations of the survival, or transmigration, of the human spirit, Browne expands his discussion to the meditation of re-collection, and the faculty of memory's fraught and failing claims upon the attentions of posterity:

To subsist in lasting Monuments, to live in their productions; to exist in their names, and prædicament of Chymera's, was large satisfaction unto old expectations, and made one part of their Elyziums. But all this is nothing in the Metaphysicks of true belief [...] We whose generations are ordained in this setting part of time [...] cannot excusably decline the consideration of that duration which maketh Pyramids pillars of snow, and all that's past a moment [...] (Browne, 1658: 78-9, 83)

By way of conclusion, it might be added that at the end of the twentieth century Andreas Huyssen was heard complaining in his remarkable critical collection Twilight Memories, 'there is a deepening sense of crisis often articulated in the reproach that our culture is terminally ill with amnesia' (Huyssen, 1995: 1). It would seem that early modern intellectuals like Donne, Jonson, Ralegh and Mary Sidney were haunted by similar conclusions concerning their age's ailing resources of memory and, if surviving documents from the period are an adequate gauge for such discussions, they may indeed have been accurate in their anxieties. In sombre fashion John Chamberlain wrote to Dudley Carleton from London on October $13^{\text {th }} 1621$

The old countesse of Pembroke died here some ten dayes since [...] The parlement is adjourned by proclamation from the $14^{\text {th }}$ of November to the $8^{\text {th }}$ of February, which beeing counted a kind of dismall day as well in other respects, as for the rising of the 
earle of Essex, $\mathrm{y}^{\mathrm{t}}$ is marvaile $\mathrm{y}^{\mathrm{t}}$ was not remembred. ('To Sir Dudley Carleton, London, October 13 1621'. In Chamberlain, 1939: II.400) 
Acknowledgements : I would like to take this opportunity to express my sincere gratitude to Kate Hodgkin and to her fellow AHRC research network coordinators, Kate Chedgzoy, Elspeth Graham and Ramona Wray, for kindly inviting me to be part of their ambitious research enquiry into early modern memory culture.

Endnotes: see below

\section{Bibliography}

Aquinas St T (2005). Commentaries on Aristotle's 'On Sense and What is Sensed' and 'On Memory and Recollection', trans K White qnd EM Macierowski. Washington DC: Catholic University of America Press.

Ariew R (2012). 'Descartes and Leibniz as Readers of Suárez: Theory of Distinctions and Principle of Individuation'. In B Hill and H Lagerlund eds (2012). The Philosophy of Francisco Suárez. Oxford: Oxford University Press, pp 38-53.

Aristotle (1984). The Complete Works of Aristotle: The Revised Oxford Translation, ed J Barnes.

Princeton: Princeton University Press.

Augustine (1991). Confessions, trans H Chadwick. New York: Oxford University Press.

Bacon Sir F (1857-74). The Works of Francis Bacon, ed J Spedding, RL Ellis, DD Heath. XIV vols. London: Longman.

Baldo J (2011). Memory in Shakespeare's Histories: Stages of Forgetting in Early Modern England. London: Routledge.

Basse W (attributed to) (1630 ( $\left.\left.2^{\text {nd }} \mathrm{ed}\right)\right)$. A Helpe to memory and discourse with table-talke as musicke to a banquet of wine : being a compendium of witty, and vsefull propositions, problemes, and sentences extracted from the larger volumes of physicians, philosophers, orators and poets, distilled in their assiduous and learned obseruations, and which for method, manner, and referent handling may be fitly tearmed, A Second misselany, or helpe to discourse. London: TB for L Becket. $1^{\text {st }}$ ed 1619 .

Baynes P (1618). A Caveat for Cold Christians. London: F Kyngston for N Newbery.

Bolzoni L (2001). The Gallery of Memory. Literary and Iconographic Models in the Age of the Printing Press. Toronto: University of Toronto Press.

Browne Sir T (1658). Hydriotaphia, urne-buriall, or, a discourse of the sepulchrall urnes lately found in Norfolk. Together with the garden of Cyrus, or the quincunciall. London: sign of the Gun in Ivy Lane for H Brome.

Burke P (1989). 'History as Social Memory', 97-113. In T Butler ed (1989). Memory: History, Culture and the Mind. Oxford: Basil Blackwell.

Camden W (1610). Britain, or A chorographicall description of the most flourishing kingdomes, England, Scotland, and Ireland, and the ilands adioyning, our of the depth of antiquitie. London: Eliot's Court Press.

Carruthers MJ (1990). The Book of Memory: a study of memory in medieval culture. Cambridge: Cambridge University Press.

Chamberlain J (1939). The Letters of John Chamberlain, ed NE McClure, II vols. Philadelphia: American Philosophical Society.

Cicero (1942). De Oratore, Books I $\mathcal{G}$ II, trans EW Sutton and H Rackham. London/Cambridge MA: William Heinemann/Harvard University Press.

Coleman J (1992). Ancient and Medieval Memories: studies in the reconstruction of the past. Cambridge: Cambridge University Press.

Collingwood RG (1924). Speculum Mentis, or the Map of Knowledge. Oxford: Clarendon Press. 
Cornwallis Sir W (1600-1). Essayes. By Sir William Corne-Waleys the younger, Knight. London: S Stafford and R Read.

Crompton R (1599). The mansion of magnanimitie. London: R Field.

Dalechamp C (1999), Artis poeticae et versificatoriae encomium. In Binns, JW (1999). Latin

Treatises on Poetry from Renaissance England: Henry Dethick 'Oration in laudem poeseos';

Alberico Gentili 'Commentatio ad Legem III Codicis de professoribus et medicis'; Caleb

Dalechamp 'Artis poeticae et versificatoriae encomium'. Signal Mountain, TE: Summertown.

De Certeau M (1988). The Writing of History, trans T Conley. New York: Columbia University Press.

Donne J (1953-62). The Sermons of John Donne, in Ten Volumes, eds GR Potter, EM Simpson.

Berkeley/Los Angeles: University of California Press.

Duffy E (2005). The Stripping of the Altars: Traditional Religion in England, c.1400-1580. New

Haven: Yale University Press.

Emerson RW (1899). The Natural History of the Intellect and Other Papers. Boston: Houghton Mifflin.

Engel WE (1995). Mapping Mortality: The Persistence of Memory and Melancholy in Early Modern

England. Amherst MA: University of Massachusetts Press.

Engel WE, Loughnane R and Williams G eds (2016). The Memory Arts in Renaissance England.

Cambridge: Cambridge University Press.

Erasmus (1976). 'To Leo X', 1 February 1516. In Erasmus (1976). The Collected Works of

Erasmus, vol. 3: The Correspondence of Erasmus - letters 298 to 445 (1514-1516), trans

RAB Mynors and DFS Thomson. Toronto: University of Toronto Press.

Erasmus (1978). De copia and De ratione studii, trans C. R. Thompson. In Collected Works of

Erasmus, vol. 24. Toronto: University of Toronto Press.

Erasmus (1988). 'On Disdaining the World/De Contemptu Mundi, trans E Rummel. In Erasmus

(1988). Collected Works of Erasmus - Spiritualia: 'Enchiridion', 'De Contemptu Mundi', 'De

Vidua Christiana', vol. 66, ed JW O'Malley. Toronto: University of Toronto Press.

Erasmus (1988a). The Correspondence of Erasmus, Letters 1122 to 1251 (1520-1521), trans RAB

Mynors \& DFS Thomson. Collected Works of Erasmus, vol. 8. Toronto: University of

Toronto Press.

Foxe J (1563). Acts and Monuments. London: John Day.

Foxe J (1570). Acts and Monuments. London: John Day.

Foxe J (1583). Acts and Monuments. London: John Day.

Freud S (1953-74). The Standard Edition of the Complete Psychological Works of Sigmund Freud, trans and ed Strachey J, Freud A., Strachey A. and Tyson A. 24 vols. London: Hogarth Press.

Gratarolo G (1562). The Castel of Memorie [...] Made by Gulielmus Gratarolus. London: Rouland Hall.

Guibbory A (1980). 'John Donne and Memory as "The Art of Salvation”, Huntington Library

Quarterly (Autumn, 1980), 43, 4, 261-274.

Guibbory A (1986). The Map of Time: seventeenth-century English literature and ideas of pattern in history. Champaign IL: University of Illinois Press.

Halbwachs M (1992). On Collective Memory, trans LA Coser. Chicago: University of Chicago Press.

Hiscock A (2011). Reading Memory in Early Modern Literature. Cambridge: Cambridge University Press.

Holinshed R (1586). The Second Volume of Chronicles: Conteining the description, conquest, inhabitation, and troblesome estate of Ireland. London: H Denham. 
Huyssen A (1995). Twilight Memories. Marking Time in a Culture of Amnesia. New York:

Routledge.

Ivic C (2017). Shakespeare and National Identity: A Dictionary. London: Bloomsbury.

Jardine D ed (1832). Criminal Trials, 2 vols. London: Charles Knight.

Karremann I (2015). The Drama of Memory in Shakespeare's History Plays. Cambridge: Cambridge

University Press.

King H (1992). The Sermons of Henry King (1592-1669) Bishop of Chichester, ed M Hobbs.

Rutherford/Madison/Teaneck: Fairleigh Dickinson UP/Scolar Press.

Lyne R (2016). Memory and Intertextuality in Renaissance Literature. Cambridge: Cambridge University Press.

MacKinnon D (2014). Earls Colne's Early Modern Landscapes. Aldershot: Ashgate.

Mignolo WD (2003). The Darker Side of the Renaissance: Literacy, Territoriality $\mathcal{E}$ Colonization.

Ann Arbor MI: University of Michigan Press.

Montaigne M de (1613). Essays written in French by Michael Lord of Montaigne [...] done into

English, according to the last French edition, by Iohn Florio. London: M. Bradwood for

Edward Blount \& William Barret.

More Sir T (1992). Utopia, trans RM Adams. New York: W. W. Norton \& Company.

Nietzsche F (1909). The Use and Abuse of History. In Nietzsche F (1909). The Complete Works of

Friedrich Nietzsche, ed O Levy, trans A Collins. Edinburgh/London: TN Foulis.

Parry G (1995). The Trophies of Time: English Antiquarians of the Seventeenth Century. Oxford:

Oxford University Press.

Pivetti K (2015). Of Memory and Literary Form: Making the Early Modern Nation. Newark DE:

University of Delaware Press.

Proctor T (1578). Of the knowledge and conducte of warres two bookes, latelye wrytten and sett foorth, profitable for suche as delight in hystoryes, or martyall affayres, and necessarye for this present tyme. London: Richard Tottel.

Prynne W (1633). Histrio-mastix The players scourge, or, actors tragaedie. London: for Michael Sparke.

Quintilian (1936). The Institutio Oratoria of Quintilian, trans HE Butler. London/Cambridge, MA: William Heinemann/Harvard University Press.

Ralegh Sir W (1634). The History of the World. London: Walter Burre.

Ralegh Sir W (1999). The Letters of Sir Walter Ralegh, ed A. Latham and J Youings. Exeter:

University of Exeter Press.

Ricoeur P (1983). Temps et récit, t. I. Paris: Le Seuil.

Ricoeur P (1984). Time and Narrative, vol. I, trans McLaughlin K and Pellauer D. Chicago:

University of Chicago Press.

Ricoeur P (2004). Memory, History, Forgetting, trans Blamey K and Pellauer D.

Chicago/London: University of Chicago Press.

Shakespeare W (1990). The First Part of King Henry VI, ed M Hattaway. Cambridge: Cambridge University Press.

Shakespeare W (1991). The Second Part of King Henry VI, ed M Hattaway. Cambridge: Cambridge University Press.

Shakespeare W (1992). King Henry V, ed A Gurr. Cambridge: Cambridge University Press.

Shakespeare W (1993). The Third Part of King Henry VI, ed M Hattaway. Cambridge: Cambridge University Press.

Shakespeare W (2003) Othello, ed N Sanders. Cambridge: Cambridge University Press.

Sherlock P (2008). Monuments and Memory in Early Modern England. Aldershot: Ashgate. 
Spenser E (1590). The Faerie Queene disposed into twelue books, fashioning XII. morall vertues. London: for William Ponsonbie.

Spenser E (1970). A View of the Present State of Ireland, ed WL Renwick. Oxford: Clarendon Press.

Stimson D (1917). The Gradual Acceptance of the Copernican Theory. New York: Columbia University Press.

Sutton C (1600). Disce mori. = Learne to die. A religious discourse, moouing euery Christian man to enter into a serious remembrance of his ende. London: J Windet for J Wolfe.

Tasso T (1600). Godfrey of Bulloigne, or The recouerie of Ierusalem. Done into English heroicall verse, by Edward Fairefax Gent. London: A Hatfield for I Iaggard and M Lownes.

Terdiman R (1993). Present Past. Modernity and the Memory Crisis. Ithaca/London: Cornell University Press.

Vine A (2010). In Defiance of Time. Antiquarian Writing in Early Modern England. Oxford: Oxford University Press.

Virgil (1990). The Aeneid, trans D West. Harmondsworth: Penguin.

Vives JL (1913). Vives: On Education. A Translation of 'De Tradendis Disciplinis' of Juan Luis Vives, trans and intro by F Watson. Cambridge: Cambridge University Press.

Walsham A (2012). The Reformation of the Landscape: Religion, Identity and Memory in Early Modern Britain and Ireland. Oxford: Oxford University Press.

Willis J (1621). The Art of Memory so far forth as it dependeth wpon places and idea's Written first in Latine, by Iohn Willis Bachelour in Diuinitie: and now published in English by the said author, with such alternations thereof as seemed needful. London: W. Jones.

Wright LB ed (1962). Advice to a Son. Precepts of Lord Burghley, Sir Walter Raleigh, and Francis Osborne. New York: Folger Shakespeare Library/Cornell University Press.

Yates FA (1966). The Art of Memory. London: Routledge and Kegan Paul.

\section{ENDNOTES}

\footnotetext{
${ }^{1}$ In this context, see also: Donne vol 2, 1953-62: esp 72ff; Guibbory, 1980 and 1986; Engel, Loughnane and Williams, 2016.

${ }^{2}$ On the memorial culture of the Catholic cultures of worship, see: Lina Bolzoni, 2001: esp 140ff; Duffy, 2005: esp 327ff..

${ }^{3}$ For further discussion here on the cultural power of forgetting, see: Baldo, 2011; Karremann, 2015; Ivic, 2017.

${ }^{4}$ In this context, see also: 'The past cannot be rendered in a neutral discourse' (Mignolo, 2003: 5).

${ }^{5}$ Translated from Latin by JW Binns: 'Quae non ad eruditionem modo conducit, sed ad civilies actiones non modicum adfert adiumentum...'

${ }^{6}$ In this context, see also the notable contribution of John Willis's The art of memory $\left(1^{\text {st }}\right.$ pub. in English, 1621).

${ }^{7}$ Translations: 'We labour, and toyle, and plod to fill the memorie, and leave both vnderstanding and conscience emptie' (Montaigne, 1613: 62); “"Knowing” something does not mean knowing it by heart; that simply means putting it in the larder of our memory' (Montaigne, 2003: 171).

${ }^{8}$ For broader discussion here, see MacKinnon, 2014; Sherlock, 2008; Walsham, 2012.
} 